\title{
Detection of Pathogen Candida spp. Isolated from Butter
}

\author{
Tereyağında Patojen Candida spp. Varlğğmn Arasttrilması
}

\author{
(iD) Özen YURDAKUL ${ }^{*}$, (D) Seval Sevgi KIRDAR², (D) Erhan KEYVAN ${ }^{1}$ \\ ${ }^{1}$ Burdur Mehmet Akif Ersoy University, Faculty of Veterinary Medecine, Department of Food Hygiene and \\ Technology, Burdur, Turkey \\ ${ }^{2}$ Burdur Mehmet Akif Ersoy University, Department of Food Processing, Milk and Dairy Products Technology \\ Programme, Burdur, Turkey
}

\begin{abstract}
Yeasts may affect food safety and quality causing spoilage in foods. Also, yeasts can be used as starter culture in the production of traditional and industrial products. But, Candida species are important for hospital infections which have been able to infect to humans via food in recent years. The aim of this study was to evaluate the incidence of pathogen Candida spp. in butter. In this study, 100 butter samples were analyzed from public bazaars. Candida spp. was detected $10 \%$ of butter samples. C. albicans, C. albicans and C. krusei, C. tropicalis, C. krusei were isolated 4\%,3\%, 2\%, 1\% from positive butter samples for Candida spp., respectively. According to this data, presence of pathogen Candida spp. in butter samples can cause significant problems for public health. In order to ensure food safety, it is necessary to determine the rate of yeast and mold and the detection of pathogen yeasts in microbiological analyses.
\end{abstract}

Keywords: Butter, Candida spp., public health, yeast and mold

Öz: Mayalar, gıdalarda bozulmalara sebep olarak gıda güvenliği ve kalitesini etkileyebilir. Ayrıca mayalar geleneksel ve endüstriyel ürünlerin üretiminde starter kültür olarak da kullanılabilir. Ancak, soon yıllarda Candida türleri grda yoluyla insanlara bulaşabilen hastane enfeksiyonlarına da neden olmaktadır. Bu çalışmada, tereyağında patojen Candida spp. varlığının araştırlması amaçlanmıştır. Halk pazarlarından toplanan toplam 100 adet tereyağı örneği analiz edildi ve bu örneklerin \% 10'u Candida spp. pozitif olarak tespit edildi. Tereyağından izole edilen Candida spp. pozitif izolatlarda C. albicans, C. albicans ve C. krusei, C. tropicalis, C. krusei varllğı sırasılla $\% 4 \% 3, \% 2, \% 1$ olarak bulundu. Patojen Candida spp.'nin tereyağ örneklerinde varlığ halk sağlığı açısından önemli problemler meydana getirebilir. Mikrobiyolojik analizlerde güvenli gıda üretiminin sağlanması amacıyla maya ve küf oranı ile birlikte patojen mayaların da tespiti gereklidir.

\begin{tabular}{ll}
\hline Anahtar Kelimeler: Candida spp., halk sağ lı̆̆ı, maya ve küf, tereyağ \\
\hline${ }^{*}$ Corresponding author : Özen YURDAKUL & e-mail : ozenkursun@mehmetakif.edu.tr \\
Geliş tarihi / Received : 12.12.2018 & Kabul tarihi / Accepted: 24.12.2018 \\
\hline
\end{tabular}

\section{Introduction}

Yeasts are spoilage microorganisms that affect the quality and safety of a wide range of foods (Betts et al., 1999). Yeasts are used traditionally in bread, beer and wine production. In addition, yeasts are used as starter culture during to ripening periods of the cheeses in order to give some special characterical properties (Loretan et al., 1998). The genus Candida are commensal eukaryotic yeast species of phylum Ascomycota group member and can be found in the environment, human and other mammals (McManus and Coleman, 2014). In mammals, Candida species are the member of normal commensal mucosal surfaces of gastrointestinal and genitourinary tracts (Kumamoto, 2011). In addition, yeasts can adversely affect food safety and cause infections as an opportunistic pathogen (Fleet, 2007). More than 17 species of Candida can cause human 
infections. Besides, Candida albicans, Candida glabrata, Candida parapsilosis, Candida tropicalis, and Candida krusei are the aetiological agents of invasive infections (Pfaller et al., 2007). C. albicans is the main reason of the oral and systemic candidiasis (Akpan and Morgan, 2002; Thompson et al., 2010).

Butter is a dairy product which is made of milk or cream (El-Diasty and Salem, 2009). Butter is highly nutritive and beneficial for the consumers (Kwak, H. S., Ganesan, P., \& Al Mijan, 2013). The microbial quality in butter may be affected by the processing methods, storage conditions and packaging (Karagözlü and Ergönül, 2008). Candida species can affect the foods as starter cultures and spoilage microorganisms (Hommel, 2014). There are numerous reports on the occurrence of pathogenic yeasts in dairy products (El-Sharoud et al., 2009; Sagdic et al., 2010; Wanderley and Andréia, 2013; Mohamed et al., 2017). Pathogen Candida spp. is a problem in human medicine. In veterinary medicine, Candida spp. have been isolated as a cause of mastitis (Crawshaw et al., 2005). The consume of contaminated milk without heat treatment or dairy products may create the risk of Candida spp. (McManus and Coleman, 2014). The presence of pathogen Candida species in foods can cause infections to human. The aim of the study was to evaluate the incidence of pathogen Candida spp. in butter.

\section{Material and Methods}

\section{Sampling}

In this study, one hundred butter samples were collected between October 2016 and December 2017 from public bazaar in Burdur. Butter samples were transported to the laboratory under refrigeration and aseptic conditions. Samples were investigated for the presence of Candida spp. Butter $(10 \mathrm{~g})$ samples were diluted with $90 \mathrm{~mL}$ of $0.1 \%$ peptone water and homogenized for 2 minutes with a Labblender 400 stomacher (Seward Laboratory, London, UK) for the enumeration of Candida spp. Serial dilutions were prepared with $9 \mathrm{~mL}$ sterile peptone water and 0.1 $\mathrm{mL}$ of each dilution was spreaded on agars. Acidified potato dextrose agar (PDA) was incubated at $25^{\circ} \mathrm{C}$ for 5-7 days for enumeration of yeasts and molds (Koburger and Marth, 1984; Tournas et al., 2001). CHROMagar Candida (CHROMagar Candida Company, Paris, France) was prepared according to the instructions of manufacturer. All plates were incubated at $30^{\circ} \mathrm{C}$ for $48 \mathrm{~h}$ aerobically, as recommended by the manufacturer (Pfaller et al., 1996). The appearance of colonies, including color, size, and textures on CHROMagar Candida, was analyzed. The color of colonies on CHROMagar Candida was similar as given by the manufacturer, green colonies of $C$. albicans, metallic blue colonies of $C$. tropicalis and by purple colored colonies of $C$. krusei.

\section{Reference strains used in testing}

ATCC 97012 C. albicans, ATCC 2011 C. tropicalis, ATCC 610 C. krusei strains were used in this study.

\section{Other tests}

Several tests were applied to the suspicious colonies for the isolation of Candida spp. as Gram staining, germ tube test, carbohydrate fermentation tests (glucose, maltose, sucrose, and galactose), and urease tests (Cooper and Margarita, 1985; Konemann et al., 1997).

\section{Results and Discussion}

One hundred butter samples were evaluated for the existence of pathogen Candida spp. in this study. Candida spp. was detected $10 \%$ of butter samples. C. albicans, C. albicans and C. krusei, C. krusei, C. tropicalis were isolated 4\%, 3\%, 2\%, 1\% from Candida spp. positive butter samples, respectively. Moreover yeast and mold counts of 100 butter samples were detected ranged from min. $2.00 \mathrm{log} \mathrm{cfu} / \mathrm{g}$ to max. $4.30 \mathrm{log} \mathrm{cfu} / \mathrm{g}$ and average $2.68 \pm 0.79 \log \mathrm{cfu} / \mathrm{g}$. El-Diasty and Salem (2009) studied on lypolitic and proteolitic fungi in dairy products and they reported that 
$10 \%$ of the butter samples contaminated with $C$. tropicalis.

In this study, pathogenic Candida spp. were isolated from butter samples. The microflora of the butter reflects the qualities of the cream, the sanitary conditions of the equipment used to produce the butter, the environmental and hygienic conditions during the packaging and transport of the butter are important factors effecting butter quality (Pal, 2014). Previous studies were reported higher levels of molds and yeasts contamination in butter as $1.7 \times 10^{4}$, $9.0 \times 10^{5}, 5.5 \times 10^{6}$, and $6.99 \times 10^{4} \mathrm{kob} / \mathrm{g}$ by Yalçın et al. (1993), Patır et al. (1995), Sancak et al. (2002) and Henin and Kalves (1992), respectively. Also, Bakirci et al. (2000) were analysed the microbiological properties of 33 culinary types of butter samples, and as a result of the study yeast and molds were found as $2.12 \mathrm{cfu} / \mathrm{g}$ in family businesses and $5.25 \mathrm{cfu} / \mathrm{g}$ in dairy farm. In another study Hayaloglu and Konar (2001) were reported that enumeration of yeast and mold of 25 butter samples as $1.0 \times 10^{3}-7.3 \times 10^{6} \mathrm{cfu} / \mathrm{g}$ in Malatya region. Karagozlu and Ergonul (2008) were observed the counts of yeast and mould in butter as $<1.0-6.66 \log \mathrm{cfu} / \mathrm{g}$. In our study, yeast and mold counts were detected as minimum 2.00 $\mathrm{cfu} / \mathrm{g}$, maximum $4.30 \mathrm{cfu} / \mathrm{g}$, and mean $2.68 \pm 0.79$ $\mathrm{cfu} / \mathrm{g}$. In our study, results were lower than previous studies.

Although there are many studies on hygiene and presence of pathogenic microorganisms in butter, it seems that there are just a few studies on the analysis of the pathogen Candida spp. Total number of yeast and molds does not refer to pathogenic Candida spp in microbiological analysis of foods. Pathogen Candida spp. constitutes major health problems in humans by developing resistance and it can cause diseases by taking contaminant foods (Wanderley and Andréia, 2013). Chromogenic media is effective for the isolation and identification of pathogen Candida spp. (Devi and Maheshwari, 2014).

Finally it could be said, microbiological analysis of food samples should be made not just for determining the total number of yeasts and molds, but the samples should also be tested for detecting the presence of pathogenic yeast, which would be very crucial for the public health. We suggest that to be aware of the presence of pathogenic Candida spp. in foods, relevant legislation should be regulated to decrease the possible risk of pathogenic Candida spp.

\section{References}

Akpan, A., Morgan, R., 2002. Oral candidiasis. Postgraduate Medical Journal 78, 455-459.

Bakırc1, I., Çelik Ş., Özdemir, S., 2000. Erzurum Piyasasında Tüketime Sunulan Mutfak Tipi Tereyağlarının Mikrobiyolojik Özellikleri. Atatürk Üniversitesi, Ziraat Fakültesi Dergisi 31, $51-55$.

Betts, G.D., Linton, P., Betteridge, R.J., 1999. Food spoilage yeasts: effects of $\mathrm{pH}, \mathrm{NaCl}$ and temperature on growth. Food Control 10, 27-33.

Cooper, B., Margarita, S., 1985. Yeast of medical importance. In: Balows A, Hausler W, Hermann K, et al. (eds) Manual of Clinical Microbiology. American Society for Microbiology, Washington DC, pp 526-541

Crawshaw, W.M., MacDonald, N.R., Duncan, G., 2005. Outbreak of Candida rugosa mastitis in a dairy herd after intramammary antibiotic treatment. The Veterinary Record 156, 812-3.

Devi, L., Maheshwari, M., 2014. Speciation of Candida Species Isolated From Clinical Specimens by Using Chrom Agar and Conventional Methods. International Journal of Scientific and Research Publications 4, 1-2.

El-Diasty, E.M., Salem, R.M., 2009. Incidence of lipolytic and proteolytic fungi in some milk products and their public health significance. Arab Journal of Biotechnology 12, 49-56.

El-Sharoud, W.M., Belloch, C., Peris, D., Querol, A., 2009. Molecular Identification of Yeasts Associated with Traditional Egyptian 
Dairy Products. Journal of Food Science 74, M341-M346.

Fleet, G.H., 2007. Yeasts in foods and beverages: impact on product quality and safety. Current Opinion in Biotechnology 18, 170-175.

Hayaloglu, A., Konar, A., 2001. Comparative Study on Microbiological Quality of Butter Produced from Yogurt and Cream in Malatya Region. Journal of Association of Food Technology 26, 429-435.

Henin, A.Y., Kaldes, Y.T., 1992. Microbiological evaluation of cooking butter manufactured in Minia Governorate. . J, 2, 2. Beni Suef Veterinary Medical Journal 2, 291-297.

Hommel, R.K., 2014. Candida. In: Batt C, Tortorello M (eds) Encyclopedia of Food Microbiology, Second. Academic Press, New York, pp 367-373

Karagözlü, N., Ergönül, B., 2008. Microbiological Attributes of Turkish Butters Sold Under Market Conditions. Journal für Verbraucherschutz und Lebensmittelsicherheit 3, 376-379.

Koburger, J., Marth, E., 1984. Yeasts and Moulds. In: Speck M (ed) Compendium of Methods for the Examination of Foods. APHA, Washington DC, pp 197-202

Konemann, W., Allen, S., Janda, M., 1997. Color Atlas and Textbook of Diagnostic Microbiology. In: 5th edn. Lippincott, New York, pp 963-1069

Kumamoto, C.A., 2011. Inflammation and gastrointestinal Candida colonization. Current Opinion in Microbiology 14, 386-391.

Kwak, H. S., Ganesan, P., \& Al Mijan, M., 2013. Butter, Ghee, and Cream Products. In: Park YW, Haenlein GFW (eds) Milk and Dairy Products in Human Nutrition: Production, Composition and Health, First. Wiley Blackwell, pp 390-411
Loretan, T., Viljoen, B.C., Mostert, J.F., Vogel, A.M., Jordaan, H.F., Du, P., 1998. A preliminary study on the diversity and technological properties of indigenous traditional South African fermented milk. In: Jakobsen M, Viljeon BC (eds) Yeasts in the Dairy Industry: Positive and Negative Aspects. International Dairy Federation, Brussels, pp 178-192

McManus, B.A., Coleman, D.C., 2014. Molecular epidemiology, phylogeny and evolution of Candida albicans. Infection, Genetics and Evolution 21, 166-178.

Mohamed, A., Ahmed, A., Amer, A., Abdelshahid, S., 2017. Incidence of Mycobiota in Some Dairy products and its Public Health Hazards Sciences Veterinary of Journal Alexandria Incidence of Mycobiota in Some Dairy products and its Public Health Hazards. AJVS 53, 203-210.

Pal, M., 2014. Spoilage of Dairy Products due to Fungi. Beverage and Food World 41, 37-40.

Patır, B., Güven, A., Saltan, S., 1995. Studies on Quality of Butter Consumed in Elazı̆̆. Selçuk Üniversitesi Veteriner Bilimleri Dergisi 11, 77-81.

Pfaller, M.A., Diekema, D.J., Procop, G.W., Rinaldi, M.G., 2007. Multicenter comparison of the VITEK 2 antifungal susceptibility test with the CLSI broth microdilution reference method for testing amphotericin B, flucytosine, and voriconazole against Candida spp. Journal of clinical microbiology 45, 3522-8.

Pfaller, M.A., Houston, A., Coffmann, S., 1996. Application of CHROMagar Candida for rapid screening of clinical specimens for Candida albicans, Candida tropicalis, Candida krusei, and Candida (Torulopsis) glabrata. Journal of clinical microbiology 34, 58-61.

Sagdic, O., Ozturk, I., Bayram, O., Kesmen, Z., Yilmaz, M.T., 2010. Characterization of Butter Spoiling Yeasts and Their Inhibition by Some Spices. Journal of Food Science 75, M597M603. 
Sancak, Y.C., İşleyici, Ö., Alişarlı, M., Akkaya, L., Elibol, C., 2002. Van'da Tüketime Sunulan Kahvaltılık Tereyağlarının Mikrobiyolojik ve Kimyasal Nitelikleri. Yüzüncü Y1l Üniversitesi Veteriner Fakültesi Dergisi 13, 108-113.

Thompson, G.R., Patel, P.K., Kirkpatrick, W.R., Westbrook, S.D., Berg, D., Erlandsen, J., Redding, S.W., Patterson, T.F., 2010. Oropharyngeal candidiasis in the era of antiretroviral therapy. Oral Surgery, Oral Medicine, Oral Pathology, Oral Radiology, and Endodontology 109, 488-495.

Tournas, V., Stack, M., Mislivec, P., Koch, H., Bandler, R., 2001. Yeasts, Molds and
Mycotoxins. Bacteriological Analytical Manuel. In: Chapter 18. https://www.fda.gov/Food/FoodScienceResear $\mathrm{ch} /$ LaboratoryMethods/ucm071435.htm.

Accessed 7 Nov 2018

Wanderley, L., Andréia, B., 2013. Occurrence and pathogenicity of Candida spp. in unpasteurized cheese. Brazilian Journal of Biosciences 11, 145-148.

Yalçın, S., Cenap Tekinşen, O., Doğruer, Y., 1993. The quality of butter consumed in Konya. Selçuk Üniversitesi Veteriner Fakültesi Dergisi 9, 20-22. 